DE

M E D I C I N A

T R O P I C A L

$\mathrm{DE}$

SÃO PAULO

JOURNAL OF THE SÃO PAULO INSTITUTE OF TROPICAL MEDICINE

${ }^{1}$ Universidade Federal do Estado do Rio de Janeiro, Serviço de Clínica Médica $10^{a}$ Enfermaria, Rio de Janeiro, Rio de Janeiro, Brazil

${ }^{2}$ Fundação Oswaldo Cruz, Laboratório de AIDS e Imunologia, Rio de Janeiro, Rio de Janeiro, Brazil

${ }^{3}$ Universidade Federal do Estado do Rio de Janeiro, Centro de Ciências Biológicas e da Saúde, Rio de Janeiro, Rio de Janeiro, Brazil

${ }^{4}$ Hospital Universitário Gaffrée e Guinle, Laboratório de Imunologia, Rio de Janeiro, Rio de Janeiro, Brazil

Correspondence to: Guilherme Almeida Rosa da Silva

Rua Mariz e Barros, 775, Tijuca, CEP 20170-901, Rio de Janeiro, RJ, Brazil Tel: +5521981868189

E-mail: drguialmeida@gmail.com

Received: 14 August 2017

Accepted: 4 January 2018

\section{Prevalence of asymptomatic urethritis by Chlamydia trachomatis and Neisseria gonorrhoeae and associated risk factors among males living with HIV-1}

\author{
Guilherme Almeida Rosa da Silva', Heloisa Loureiro de Sá Neves Motta', \\ Erik Friedrich Alex de Souza', Pedro Afonso Nogueira Moises Cardoso', \\ José Henrique Pilotto ${ }^{2}$, Walter Araujo Eyer-Silva ${ }^{3}$, Luiz Cláudio Pereira \\ Ribeiro ${ }^{4}$, Mônica Soares dos Santos ${ }^{4}$, Marcelo Costa Velho Mendes de \\ Azevedo', Jorge Francisco da Cunha Pinto', Rogerio Neves Motta1, \\ Fernando Raphael de Almeida Ferry ${ }^{3}$
}

\section{ABSTRACT}

Objectives: The increase in HIV transmissibility in non-ulcerative sexually transmitted infection is already well-established. It is estimated that symptomatic carriers of N. gonorrhoeae and C. trachomatis have a relative risk of 4.8-fold and 3.6-fold, respectively, for the sexual acquisition of HIV. This type of evaluation for asymptomatic urethritis is necessary to reinforce strategies to combat HIV transmission. This study aims to assess the prevalence of patients with asymptomatic urethritis among men diagnosed with HIV-1 and determine the risk factors associated with this infection. Methods: We enrolled a total of 115 male patients aged 18 years or older who have been diagnosed with HIV infection and have no symptoms of urethritis or other sexually transmitted infections and who have been evaluated between May and August 2015 in a follow-up visit at the Immunology Outpatient Clinic of a Brazilian University Hospital. Results: Four asymptomatic patients were positive for $C$. trachomatis and were considered asymptomatic carriers of urethritis. Prevalence was $3.47 \%$. Patients who were positive for $C$. trachomatis urethritis had a lower mean age $(p=0.015)$. Conclusion: The presence of asymptomatic sexually transmitted infection is a challenge in clinical practice. We recommend that, in outpatient practice, the habit of inquiring on previous sexual behavior to obtain more information about risks and associations with asymptomatic sexually transmitted infection, a routine physical examination and complementary tests to detect STI pathogens should be performed to discard these conditions. The development of rapid tests for this purpose should also be encouraged.

KEYWORDS: HIV. AIDS. Urethritis. Chlamydia trachomatis. Neisseria gonorrhoeae

\section{INTRODUCTION}

Chlamydia trachomatis is the etiological agent of the most prevalent sexually transmitted infection (STI) worldwide ${ }^{1}$. Considering that a large percentage of $C$. trachomatis infections is asymptomatic, many countries have established public health strategies for infection screening and $\operatorname{control}^{2,3}$. In a study that aimed to ascertain the prevalence of asymptomatic urethritis by $C$. trachomatis in military men aged 17 to 24 years in Brazil, a prevalence of 5\% was found among 523 individuals using urine samples tested by polymerase chain reaction $(\mathrm{PCR})^{3}$. Other similar studies in the United States showed a prevalence of $1.5 \%, 3.7 \%$ and $5.7 \%{ }^{4-6}$. 
Regarding the prevalence of asymptomatic urethritis by Neisseria gonorrhoeae among men, one study showed a prevalence of $0.6 \%$ of $N$. gonorrhoeae urethritis and $5.7 \%$ of $C$. trachomatis. In total, $86 \%$ of $C$. trachomatis carriers and $60 \%$ of $N$. gonorrhoeae carriers were asymptomatic. This study demonstrated that, in addition to the finding that C. trachomatis is a more prevalent cause of urethritis, it is more frequently asymptomatic than $N$. gonorrhoeae ${ }^{7}$. Few studies have determined the risk profile for asymptomatic carriers of $C$. trachomatis. The main risk factors established in the literature are: age under 25 years, irregular use or negligence in condom use, new sexual partners for less than 60 days and STI history, without a direct reference to $\operatorname{AIDS}^{8,9}$.

The increase in HIV transmissibility in non-ulcerative STI is already well-established. This type of evaluation of asymptomatic urethritis is necessary to reinforce strategies to combat HIV transmission. It is estimated that symptomatic carriers of $N$. gonorrhoeae and $C$. trachomatis have a relative risk of 4.8 and 3.6, respectively, for the sexual acquisition of $\mathrm{HIV}^{10}$. A review of studies related to STI and HIV transmissibility concluded that the relative risk for transmission was between two and five and that early and strict STI control would undoubtedly have an impact on the virus transmissibility ${ }^{11}$.

In a study that aimed to measure the seminal viral load among HIV-infected individuals with symptomatic urethritis, HIV viral load in the semen of these individuals was eight times higher than in patients without symptomatic urethritis. Gonorrhea was the urethritis etiology with the greater strength of association, and, after treatment, there was a significant drop of HIV viral load in the semen $^{12}$.

Considering that the history of STI is a risk factor for asymptomatic urethritis, we could expect that HIV-positive patients would have a higher prevalence of the disease. Theoretically, the immunodeficiency status associated with HIV infection may cause the subject to be less symptomatic because of a lower local immune response, and individuals with a lower $\mathrm{CD}^{+}$T-lymphocyte count could be more prone to asymptomatic urethritis. Among those with a CD4 ${ }^{+}$T-lymphocyte count that is lower than 200 cells $/ \mathrm{mm}^{3}$, trimethoprim-sulfamethoxazole (TMS) prophylaxis against pneumocystosis and neurotoxoplasmosis could treat possible asymptomatic urethritis, and, among those with a CD4 ${ }^{+} \mathrm{T}$-lymphocyte count lower than 50 cells $/ \mathrm{mm}^{3}$, azithromycin prophylaxis against Mycobacterium avium complex could treat possible asymptomatic urethritis, consequently reducing the prevalence in this group ${ }^{12}$.

This study aims to assess the prevalence of patients with asymptomatic urethritis caused by $C$. trachomatis and
$N$. gonorrhoeae among men diagnosed with HIV-1 and determine the risk factors associated with this infection. We have also studied associations with sexual behavior and condom use in this population.

\section{MATERIALS AND METHODS}

\section{Patient Recruitment}

In this analytical cross-sectional study, a total of 115 male patients were enrolled, including only those who were diagnosed with HIV infection and no symptoms of urethritis or other STI, aged 18 years or older, who were evaluated between May and August of 2015, among a total of 314 patients in a follow-up visit at the Immunology Outpatient Clinic of the Gaffrée and Guinle University Hospital. The Hospital was chosen because it is one of the biggest centers in number of patients and one of the main references in the treatment of HIV infection in the country. Exclusion criteria were: refusal to participate in the study (13 patients $-4.1 \%$ ), younger than 18 years (99 patients $-31.5 \%$ ), those who were unable to perform the exams, patients presenting with urinary symptoms ( 27 patients $-8.5 \%$ ), or who did not attend the scheduling phases of collection or treatment (60 patients $-19.1 \%$ ). All patients signed informed consent forms and the study followed all the guidelines for experimental investigation and ethical standards with human subjects required by the institution and Resolution 466/2012 of the Brazilian National Health Council (CNS) on Ethics in Research with human beings Treatment with azithromycin $1 \mathrm{~g}$ orally in a single dose was offered free of charge for all diagnosed patient and partner(s).

\section{Specimen Collection and Laboratory Testing}

The clinical and epidemiological study consisted of data collection from medical records and interviews conducted by the researcher responsible for data collection, regarding age, date of birth, place of residence, date of first attendance, date of first anti-HIV-1 positive exam, date of onset of antiretroviral (ART) regimen, ART treatment (yes or no), current ART regimen, outpatient follow-up (in years), marital status, schooling (in years), circumcision (yes or no), virus exposure category (sexual, parenteral, vertical), sexual habits (men and/or women), previous use of antibiotics in the past year, use of antibiotic prophylaxis, frequency of condom use, alcoholism defined as the regular use of alcoholic beverages in quantities sufficient to cause significant social, interpersonal, family and/or organic problems and use of illicit drugs. 


\section{Demographic and Clinical Data Collection}

Urine was collected and tested by real-time PCR for the detection of C. trachomatis and N. gonorrhoeae (Abbott RealTime CT/NG test ${ }^{\circledR}$ ). Simultaneous blood collection was performed to obtain HIV viral load values (detection level of 40 copies $/ \mathrm{ml}$ ) and $\mathrm{CD} 4^{+}$T-lymphocyte counts.

\section{Data Analysis and Statistical Calculations}

The descriptive analysis of the data was performed by calculating the mean and standard deviation for continuous variables and the frequency analysis for categorical variables. The associations between categorical and continuous variables were assessed by analysis of variance followed by comparison of means by the t-test, of categorical variables by the chi-square test and of continuous variables by linear correlation analyzing the $\beta$ (angular coefficient) and $\mathrm{R}^{2}$ (coefficient of determination). The non-parametric Wilcoxon-Mann-Whitney test was used for analysis between two independent populations with categorical variable distributions. We used a multivariate logistic regression using as covariates those which were statistically significant, binaries and categorical, in order to identify variables independently associated with the diagnosis of asymptomatic urethritis. The level of statistical significance was set to $5 \%$. The programs SPSS ${ }^{\circledR} 17.0$ and Epi Info $7^{\circledR}$ were used for analyses.

\section{Ethical Approval}

This study was approved by the Ethical Committee from UNIRIO, Rio de Janeiro, Brazil. Process $\mathrm{N}^{\circ}$ 02366912.1.0000.5248.

\section{RESULTS}

\section{Patient Recruitment and Demographics}

We evaluated 115 male patients who met the inclusion criteria of the study. After the information collection with the help of medical records, the interview and the laboratory tests, the profile of the studied population could be determined (Tables 1 and 2). The mean age of the studied participants was 44.57 years, the majority $(74.8 \%)$ was unmarried and $37.4 \%$ had completed high school.

\section{HIV treatment}

Regarding the AIDS treatment data, the mean time of diagnosis was 10.45 years, with an average of 4.64 years of
ART, of which $91.2 \%$ of the patients were using ART, $17.5 \%$ were on prophylaxis with TMS with or without macrolide, mean CD4 ${ }^{+}$T-lymphocyte count of 499.61 cells $/ \mathrm{mm}^{3}$, and $70.5 \%$ of patients had undetectable plasma HIV viral load. Most of them (61.7\%) denied the use of any antibiotic in the past year.

\section{Behavior and Condom Use}

Regarding lifestyle habits, $96.5 \%$ of the patients reported sexual intercourse as the form of acquisition of the HIV infection, with $38.3 \%$ of patients reporting sexual practices only with women, $30.4 \%$ reporting sexual practices only with men and $31.3 \%$ reporting sexual practices with men and women. The majority (78.3\%) had already had insertive anal sex, and the majority (56.5\%) reported using condoms in more than $50 \%$ of intercourses. Of those studied, $19.1 \%$ were circumcised, $9.7 \%$ reported having problems with alcoholism and $27 \%$ used some type of illicit drug.

\section{Prevalence of Urethritis}

Results obtained from PCR of urine samples revealed that, in the sample of 115 patients, four were asymptomatic carriers of urethritis, all of them were positive only for $C$. trachomatis. Prevalence of asymptomatic urethritis was $3.47 \%$. The comparison of the descriptive data between the group with asymptomatic urethritis and the group without asymptomatic urethritis is shown in Tables 1 and 2 .

\section{Data analysis}

After statistical analysis, we observed that age is associated with the ART use time ( $\beta=$ positive, $R^{2}=0.082$, $\mathrm{p}<0.01$ ) and that the mean age of patients who do not use condoms is higher than those who use condoms in more than or equal to $50 \%$ of the intercourses ( $p=0.03$ ). Likewise, the mean age in patients who use condoms in less than $50 \%$ of intercourses is higher than that of patients who use condoms in more than or equal to $50 \%$ of intercourses $(\mathrm{p}=0.04)$.

Being a single man is associated with sexual intercourse with other men or with men and women $(\mathrm{OR}=11.9$ $(4.25-33) \mathrm{p}<0.01)$ and condom use in more than $50 \%$ of intercourses $(\mathrm{OR}=3.4(1.39-8.15) \mathrm{p}<0.01)$. The time since diagnosis was associated with the ART use time $(\mathrm{p}=0.01)$ and the ART use at all $(\mathrm{p}=0.021)$. The ART use time is associated with the CD4 $4^{+} \mathrm{T}$-lymphocyte count ( $\beta=$ positive, $\mathrm{R}^{2}=0.073, \mathrm{p}<0.01$ ), and those with undetectable HIV plasma viral loads have a longer mean ART time $(\mathrm{p}<0.01)$. Those who do not use ART are associated with a higher mean $\mathrm{CD} 4^{+} \mathrm{T}$-lymphocyte count $(\mathrm{p}=0.015)$, while those 
Table 1 - Descriptive analysis and associations between the group with and without urethritis including treatment variables $(\mathrm{N}=115)$

\begin{tabular}{|c|c|c|c|c|c|c|}
\hline \multirow[b]{2}{*}{ Variables } & & \multicolumn{3}{|c|}{ Frequencies or means \pm SD } & \multirow{2}{*}{$\begin{array}{c}\text { OR } \\
95 \% \mathrm{Cl}\end{array}$} & \multirow[b]{2}{*}{$p$-value } \\
\hline & & $\begin{array}{c}\text { Total } \\
(\mathrm{N}=115)\end{array}$ & $\begin{array}{l}\text { No Urethritis } \\
(\mathrm{N}=111)\end{array}$ & $\begin{array}{l}\text { Urethritis } \\
(\mathrm{N}=4)\end{array}$ & & \\
\hline Age (years) & & $44.57 \pm 10.9$ & $45.04 \pm 10.6$ & $31.5 \pm 15.15$ & - & $0.015^{*}$ \\
\hline \multirow{4}{*}{ Marital status } & Single & $86 / 115(74.8 \%)$ & $83 / 111(74.8 \%)$ & $3 / 4(75 \%)$ & - & \\
\hline & Married & $23 / 115(20 \%)$ & 22/111 (19.8\%) & $1 / 4(25 \%)$ & & \\
\hline & Divorced & $4 / 115(3.5 \%)$ & $4 / 111(3.7 \%)$ & $0 / 4(0 \%)$ & & \\
\hline & Widower & $2 / 115(1.7 \%)$ & $2 / 111(1.8 \%)$ & $0 / 4(0 \%)$ & & 0.94 \\
\hline \multirow{5}{*}{ Schooling } & $<6$ yrs & $14 / 115(12.2 \%)$ & $14 / 111(12.6 \%)$ & $0 / 4(0 \%)$ & & \\
\hline & $6-10$ yrs & $18 / 115(15.6 \%)$ & $16 / 111(14.6 \%)$ & $2 / 4(50 \%)$ & & \\
\hline & $10-13$ yrs & $54 / 115(47 \%)$ & $53 / 111(47.6 \%)$ & $1 / 4(25 \%)$ & & \\
\hline & Incompl. graduation & $13 / 115(11.3 \%)$ & $13 / 111(11.7 \%)$ & $0 / 4(0 \%)$ & & \\
\hline & Compl. graduation & 16/115 (13.9\%) & 15/111 (13.5\%) & $1 / 4(25 \%)$ & & 0.77 \\
\hline Time diagnosis (yrs) & & $10.45 \pm 7.42$ & $10.67 \pm 7.45$ & $4.5 \pm 2.64$ & - & 0.13 \\
\hline Time ART (yrs) & & $4.64 \pm 4.13$ & $4.7 \pm 4.17$ & $2.67 \pm 1.52$ & - & 0.4 \\
\hline \multirow{2}{*}{ ARV } & No & $10 / 115(8.7 \%)$ & $9 / 111(8.1 \%)$ & $1 / 4(25 \%)$ & 0.26 & \\
\hline & Yes & $105 / 115(91.3 \%)$ & 102/111 (91.9\%) & $3 / 4(75 \%)$ & $(0.1-2.8)$ & 0.3 \\
\hline \multirow{2}{*}{ Prophylaxis } & No & $94 / 115(82.5 \%)$ & $90 / 111(82 \%)$ & $4 / 4(100 \%)$ & & \\
\hline & Yes & $21 / 115$ (17.5\%) & $21 / 111(18 \%)$ & $0 / 4(0 \%)$ & Undefined & 0.44 \\
\hline \multirow{3}{*}{$\begin{array}{l}\text { Currently Antibiotic } \\
\text { prophylaxis }\end{array}$} & none & 96/115 (83.3\%) & $92 / 111(82.8 \%)$ & $4 / 4(100 \%)$ & - & \\
\hline & TMS & $6 / 115(5.3 \%)$ & $6 / 111(5.5 \%)$ & $0 / 4(0 \%)$ & & \\
\hline & Macrolide+TMS & $13 / 115(11.4 \%)$ & 13/111 (11.7\%) & $0 / 4(0 \%)$ & & 0.36 \\
\hline \multirow{2}{*}{ Antibiotic last year } & No & $71 / 115(61.7 \%)$ & $70 / 111(63 \%)$ & $1 / 4(25 \%)$ & 5.1 & \\
\hline & Yes & 44/115 (38.3\%) & $41 / 111(37 \%)$ & $3 / 4(75 \%)$ & $(0.5-50.0)$ & 0.15 \\
\hline \multirow{10}{*}{ Antibiotic type } & none & $71 / 115(61.7 \%)$ & $70 / 111(63 \%)$ & $1 / 4(25 \%)$ & - & \\
\hline & macrolide & 4/115 (3.4\%) & 4/111 (3.6\%) & $0 / 4(0 \%)$ & & \\
\hline & TMS & $7 / 115(6.1 \%)$ & $6 / 111(5.5 \%)$ & $1 / 4(25 \%)$ & & \\
\hline & penicillin & 18/115 (15.7\%) & $16 / 111(14.4 \%)$ & $2 / 4(50 \%)$ & & \\
\hline & cephalosporins & $5 / 115(4.4 \%)$ & $5 / 111(4.5 \%)$ & $0 / 4(0 \%)$ & & \\
\hline & quinolone & $1 / 115(0.8 \%)$ & $1 / 111(0.9 \%)$ & $0 / 4(0 \%)$ & & \\
\hline & RIPE & $5 / 115(4.4 \%)$ & $5 / 111(4.5 \%)$ & $0 / 4(0 \%)$ & & \\
\hline & aminoglicoside & $1 / 115(0.8 \%)$ & $1 / 111(0.9 \%)$ & $0 / 4(0 \%)$ & & \\
\hline & fluconazol & $1 / 115(0.8 \%)$ & $1 / 111(0.9 \%)$ & $0 / 4(0 \%)$ & & \\
\hline & multiple & 2/115 (1.9\%) & $2 / 111(1.8 \%)$ & $0 / 4(0 \%)$ & & 0.24 \\
\hline $\begin{array}{l}\text { Asymptomatic } \\
\text { urethritis }\end{array}$ & & $3.47 \%$ & $0 \%$ & $100 \%(\mathrm{CT})$ & & - \\
\hline
\end{tabular}

OR - odds ratio, $95 \% \mathrm{Cl}$ - confidence interval 95\%, SD - standard deviation, RIPE - rifampicin/isoniazide/pirazinamide/ethambutol, Antibiotic prophylaxis correspond to those individuals who were currently using antibiotics with CD4 count bellow 200 (TMS) or 50 cels $/ \mathrm{mm}^{3}$ (Macrolide+TMS). * $(p<0,05)$.

who use ART are associated with undetectable plasma HIV viral load $(\mathrm{OR}=0.1(0.01-0.4) \mathrm{p}<0.01)$.

Uncircumcised men are associated with the highest plasma HIV viral loads among patients with detectable HIV load when compared to circumcised men ( $\mathrm{p}<0.01$ ). Patients requiring prophylaxis $\left(\mathrm{CD}^{+} \mathrm{T}\right.$-lymphocyte count
$<200$ cell $/ \mathrm{mm}^{3}$ ) are associated with detectable HIV viral load $(\mathrm{OR}=4.7(1.62-13.6) \mathrm{p}<0.01)$. There was only a tendency of association $(p=0.06)$ between the use of prophylaxis with the mean $\mathrm{CD}^{+}{ }^{+} \mathrm{T}$-lymphocyte count.

When we evaluated the category of exposure to HIV, we concluded that parenteral exposure is associated with 
Table 2 - Descriptive analysis and associations between the group with and without urethritis including behavior variables $(\mathrm{N}=115)$

\begin{tabular}{|c|c|c|c|c|c|c|}
\hline \multirow[b]{2}{*}{ Variables } & & \multicolumn{3}{|c|}{ Frequencies or means \pm SD } & \multirow{2}{*}{$\begin{array}{c}\text { OR } \\
95 \% \mathrm{Cl}\end{array}$} & \multirow[b]{2}{*}{$p$-value } \\
\hline & & $\begin{array}{c}\text { Total } \\
(\mathrm{N}=115)\end{array}$ & $\begin{array}{l}\text { No Urethritis } \\
(N=111)\end{array}$ & $\begin{array}{l}\text { Urethritis } \\
(\mathrm{N}=4)\end{array}$ & & \\
\hline \multirow{3}{*}{ Sexual behavior } & Only men & $35 / 115(30.4 \%)$ & $33 / 111(29.7 \%)$ & $2 / 4(50 \%)$ & - & \\
\hline & Only women & $44 / 115(38.3 \%)$ & $42 / 111(37.9 \%)$ & $2 / 4(50 \%)$ & & \\
\hline & men and women & $36 / 115(31.3 \%)$ & $36 / 111(32.4 \%)$ & $0 / 4(0 \%)$ & & 0.18 \\
\hline \multirow{2}{*}{ Insertive anal sex } & No & 25/115 (21.7\%) & $25 / 111(22.5 \%)$ & $0 / 4(0 \%)$ & & \\
\hline & Yes & $90 / 115(78.3 \%)$ & $86 / 111(77.5 \%)$ & $4 / 4(100 \%)$ & Undefined & 0.36 \\
\hline \multirow{3}{*}{ Condom } & never & $10 / 115(8.7 \%)$ & $10 / 111(9 \%)$ & $0 / 4(0 \%)$ & - & \\
\hline & $<50 \%$ & 40/115 (34.8\%) & $39 / 111(35.2 \%)$ & $1 / 4(25 \%)$ & & \\
\hline & $\geq 50 \%$ & $65 / 115(56.5 \%)$ & $62 / 111(55.9 \%)$ & $3 / 4(75 \%)$ & & 0.41 \\
\hline \multirow{2}{*}{ Circuncision } & No & $93 / 115(80.9 \%)$ & $89 / 111(80.2 \%)$ & $4 / 4(100 \%)$ & & \\
\hline & Yes & 22/115 (19.1\%) & $22 / 111(19.8 \%)$ & $0 / 4(0 \%)$ & Undefined & 0.42 \\
\hline \multirow{3}{*}{ Exposure to HIV } & Sexual & $111 / 115(96.5 \%)$ & 107/111 (96.4\%) & $4 / 4(100 \%)$ & - & \\
\hline & Parenteral & $4 / 115(3.5 \%)$ & $4 / 111(3.6 \%)$ & $0 / 4(0 \%)$ & & \\
\hline & Vertical & $0 / 115(0 \%)$ & $0 / 111(0 \%)$ & $0 / 4(0 \%)$ & & 0.7 \\
\hline \multirow{2}{*}{ Alcoholism } & No & $105 / 115(91.3 \%)$ & $101 / 111(91 \%)$ & $4 / 4(100 \%)$ & & \\
\hline & Yes & $10 / 115(9.7 \%)$ & $10 / 111(9 \%)$ & $0 / 4(0 \%)$ & Undefined & 0.69 \\
\hline \multirow{2}{*}{ Illicit drug use } & No & $84 / 115(73 \%)$ & $81 / 111(73 \%)$ & $3 / 4(75 \%)$ & 0.9 & \\
\hline & Yes & $31 / 115(27 \%)$ & $30 / 111(27 \%)$ & $1 / 4(25 \%)$ & $(0.1-9.0)$ & 0.7 \\
\hline \multirow{7}{*}{ Drug type } & none & $83 / 115(73 \%)$ & $80 / 111(72 \%)$ & $3 / 4(75 \%)$ & - & \\
\hline & marijuana & $7 / 115(6.1 \%)$ & $7 / 111(6.6 \%)$ & $0 / 4(0 \%)$ & & \\
\hline & marijuana+cocaine & $12 / 115(10.4 \%)$ & $11 / 111(10 \%)$ & $1 / 4(25 \%)$ & & \\
\hline & cocaine & $7 / 115(6.1 \%)$ & $7 / 111(6.6 \%)$ & $0 / 4(0 \%)$ & & \\
\hline & hashish & $1 / 115(0.9 \%)$ & $1 / 111(0.9 \%)$ & $0 / 4(0 \%)$ & & \\
\hline & $\geq 3$ drugs & $5(3.5 \%)$ & $5 / 111(4.5 \%)$ & $0 / 4(0 \%)$ & & \\
\hline & outras & $0 / 115(0 \%)$ & $0 / 111(0 \%)$ & $0 / 4(0 \%)$ & & 0.89 \\
\hline $\mathrm{CD4}^{+}\left(\right.$cells $\left./ \mathrm{mm}^{3}\right)$ & & $499 \pm 311$ & $494 \pm 311$ & $640 \pm 318$ & - & 0.35 \\
\hline \multirow{2}{*}{ Viral load } & undetectable & $81 / 115(70.5 \%)$ & 79/111 (71.2\%) & $2 / 4(50 \%)$ & & \\
\hline & detectable & $34 / 115(29.5 \%)$ & $32 / 111(28.8 \%)$ & $2 / 4(50 \%)$ & & 0.33 \\
\hline Viral load (copies/ml) & & $100719 \pm 213372$ & $106584 \pm 219028$ & $9814 \pm 9318$ & & 0.54 \\
\hline $\begin{array}{l}\text { Asymptomatic } \\
\text { urethritis }\end{array}$ & & $3.47 \%$ & $0 \%$ & $100 \%(\mathrm{CT})$ & & - \\
\hline
\end{tabular}

OR - odds ratio, $95 \% \mathrm{Cl}$ - confidence interval $95 \%, \mathrm{SD}-$ standard deviation. ${ }^{*}(\mathrm{p}<0,05)$.

alcoholism $(\mathrm{OR}=12.8(1.59-103) \mathrm{p}<0.01)$. Among patients with detectable HIV viral load, those who are illicit drug users are associated with the lowest mean plasma HIV viral loads $(\mathrm{p}=0.02)$. Of the evaluated patients, the $\mathrm{CD} 4^{+}$ T-lymphocyte count is associated with HIV viral load among patients with detectable HIV load $(\beta=$ negative, $\mathrm{R}^{2}=0.2, \mathrm{p}<0.01$ ).

Patients positive for C. trachomatis urethritis had a lower mean age $(p=0.015)$. An overview of the associations found in the described sample is included in Tables 3, 4 and 5.

\section{DISCUSSION}

The study shows that a portion of the male patients living with HIV and treated in a large reference center for AIDS present with asymptomatic urethritis. We report a prevalence of $3.47 \%$ of asymptomatic urethritis in the studied sample, all cases caused by $C$. trachomatis. These data can be compared with studies in the general population without HIV infection, which report a prevalence of asymptomatic urethritis of 5\% in military men in Brazil 
Table 3 - Statistically significant associations between continuous variables $(N=115)$

\begin{tabular}{lc}
\hline Variable & Result \\
\hline Age $x$ Time of use of ARV & $\beta=$ positive, $R^{2}=0.082 p<0.01$ \\
Time since diagnosis $x$ Time of use of ARV & $\beta=$ positive, $R^{2}=0.231 p<0.01$ \\
Time of use of ARV $x$ CD4 ${ }^{+}$ & $\beta=$ positive, $R^{2}=0.073 p<0.01$ \\
CD4 $4^{+}$x detectable viral load & $\beta=$ negative, $R^{2}=0.2 p<0.01$ \\
\hline
\end{tabular}

ARV - antirretroviral, $\beta$ - angular coefficient, $R^{2}$ - determination coefficient.

Table 4 - Statistically significant associations between continuous and categorical variables $(\mathrm{N}=115)$

\begin{tabular}{|c|c|c|c|}
\hline \multirow{2}{*}{ Continuous variable } & \multicolumn{2}{|c|}{ Categorical variable $( \pm S D)$} & \multirow{2}{*}{ Result } \\
\hline & No Condom use & Condom use $\geq 50 \%$ & \\
\hline \multirow[t]{2}{*}{ Age (years) } & $53.6 \pm 7.42$ & $41.2 \pm 11.18$ & $p=0.03$ \\
\hline & Condom use < $50 \%$ & Condom use $\geq 50 \%$ & \\
\hline \multirow[t]{2}{*}{ Age (years) } & $47.78 \pm 9.21$ & $41.2 \pm 11.18$ & $P=0.04$ \\
\hline & ARV use (yes) & ARV use (no) & \\
\hline \multirow[t]{2}{*}{ Time since diagnosis (years) } & $11.06 \pm 7.37$ & $3.44 \pm 3.5$ & $p<0.01$ \\
\hline & alcoholism (yes) & alcoholism (no) & \\
\hline \multirow[t]{2}{*}{ Time since diagnosis (years) } & $16.5 \pm 8.86$ & $9.86+7.04$ & $p<0.01$ \\
\hline & Detectable viral load & undetectable viral load & \\
\hline \multirow[t]{2}{*}{ Time of use of ARV } & $4.44 \pm 5.07$ & $4.81 \pm 3.82$ & $p<0.01$ \\
\hline & ARV (yes) & ARV (no) & \\
\hline \multirow[t]{2}{*}{$\mathrm{CD}^{+}$} & $489.76 \pm 299.99$ & $601.1 \pm 419$ & $p=0.015$ \\
\hline & circuncision (sim) & circuncision (no) & \\
\hline \multirow[t]{2}{*}{ Viral load (detectables) } & $7569 \pm 15604$ & $130527 \pm 238358$ & $p<0.01$ \\
\hline & Illicit drugs (yes) & Illicit drugs (no) & \\
\hline Viral load (detectables) & $42733 \pm 86483$ & $125930 \pm 246920$ & $p=0.02$ \\
\hline
\end{tabular}

DP - standard deviation, ARV - antirretroviral.

Table 5 - Statistically significant associations between categorical variables $(N=115)$

\begin{tabular}{lcc}
\hline \multicolumn{1}{c}{ Variable } & & Result \\
\hline single & Sex with men & OR $=11.9(95 \% \mathrm{Cl}: 4.25-33) \cdot \mathrm{p}<0.01$ \\
single & Condom use $\geq 50 \%$ & OR $=3.4(95 \% \mathrm{Cl}: 1.39-8.15) \cdot \mathrm{p}<0.01$ \\
ARV use & Detectable viral load & OR $=0.1(95 \% \mathrm{Cl}: 0.01-0.4) \cdot \mathrm{p}<0.01$ \\
Prophylaxis for opportunistic infections & Detectable viral load & OR $=4.7(95 \% \mathrm{Cl}: 1.62-13.6) \cdot \mathrm{p}<0.01$ \\
Parenteral exposure & alcoholism & OR $=12.8(95 \% \mathrm{Cl}: 1.59-103) \mathrm{p}<0.01$ \\
\hline
\end{tabular}

OR - odds ratio (confidence interval), ARV - antiretroviral

and other similar studies in the United States that presented prevalence of $1.5 \%, 3.7 \%$ and $5.7 \% \%^{4-7}$.

Studies on asymptomatic urethritis specifically in the male population living with HIV are scarce, as far as we know there are only three. One from the University of Birmingham published in 1999 showed a prevalence of $8 \%$ of asymptomatic urethritis; the second study from
Johannesburg, published in 2012, presented a prevalence of asymptomatic urethritis due to $C$. trachomatis of $2 \%$ and asymptomatic urethritis due to $N$. gonorrhoeae of 4\%. The third, from New Orleans published in 2003, showed a prevalence of asymptomatic urethritis due to C. trachomatis of $2.1 \%$ and asymptomatic urethritis due to $N$. gonorrhoeae of $1.7 \%$. A broader assessment of the 
variables associated with the presence of asymptomatic urethritis was not extensively explored in the cited studies. The relevant associations found were a history of venereal lymphogranuloma in the last 12 months and positive serology for herpes simplex virus type $2^{13-15}$. The absence of $N$. gonorrhoeae causing asymptomatic urethritis in our samples could be explained by local epidemiologic factors and antibiotic use in the last year in $38.2 \%$ of all patients.

During the early epidemic period, it was recognized that the coexistence of STI increases the risk of HIV transmission and that control of these diseases is a measure not to be neglected, especially in populations with a high prevalence of HIV infection, low prevalence of circumcised individuals and among those who engage in sexual practices that brings about a higher risk of transmission ${ }^{16}$. The presence of asymptomatic STI is a challenge for clinical practice $^{11}$. We recommend that, in outpatient practice, the habit of inquiring on previous sexual behavior to obtain more information about risks and associations with asymptomatic STI, a routine physical examination and complementary tests to detect STI pathogens should be performed to discard these conditions. The development of rapid tests for this purpose should also be encouraged.

Regarding the associations found, we can say that the association between age and ART use time was influenced by temporal probability; thus, the patients aged while using ART. Patients who have used ART for a longer time also have a longer time since the diagnosis of the HIV infection and higher $\mathrm{CD} 4^{+} \mathrm{T}$-lymphocyte counts with an undetectable viral load. Individuals with detectable viral loads have a lower CD4+T-lymphocyte count. Subjects who did not use ART, corresponding to $8.8 \%$ of the sample, had a higher $\mathrm{CD} 4{ }^{+} \mathrm{T}$-lymphocyte count, which would explain the noninitiation of ART by individualized medical decisions. Patients using prophylaxis are associated with detectable viral loads, which may reflect clinical and antiviral failure or even poor adherence to treatment. All these claims have biological plausibility and are expected in individuals being treated for HIV infections.

The mean age of the patients is higher in categories where condom use is less frequent. These data reflect a resistance of the older age groups regarding the use of condoms, which may be influenced by cultural sexual behaviors of their youth.

Uncircumcised men are associated with the highest mean plasma HIV viral load among patients with detectable HIV viral loads compared to circumcised ones. The presence of inflammatory processes in the foreskin (balanitis) could negatively influence viral load control and increase viral replication in these individuals. This hypothesis needs to be confirmed in subsequent studies.
Patients positive for $C$. trachomatis urethritis have a lower mean age compared to non-urethritis individuals, although the lower mean age was associated with the more frequent use of condoms in the sample studied.

About the limitations, the study is limited to just one Hospital that is reference in treating patients living with HIV so that the population studied cannot be considered representative of all males living with HIV in Brazil. As a cross-sectional study, exposure and outcomes were simultaneously assessed and, in general, there is no evidence of a temporal relationship. It would be interesting to study asymptomatic urethritis among people living with HIV in the group younger than 18 years old. This group has an own pattern of socio demographic and behavioral characteristics and can have different prevalence of asymptomatic urethritis compared to our study. The refusal rate to participate in the study (13 patients $-4.1 \%$ ), those who were declared unable to perform the exams (27 patients $-8.5 \%$ ), or did not attend the scheduling phases of the collection or treatment (60 patients $-19.1 \%$ ) corresponded to $31.7 \%$ of the initial sample (314 patients). Those unable to perform the exams had some kind of genitourinary problem, for example, urinary infection symptoms (considered not asymptomatic). Individuals that refused to participate or missed the scheduled exams (23.2\%) could generate bias in our results, as long as this kind of situation is considered a standard of health neglect, raising the possibility that this group can have a higher prevalence of asymptomatic urethritis.

In conclusion, asymptomatic urethritis in male populations living with HIV should not be neglected and may possibly play a role in HIV transmission.

\section{CONFLICT OF INTERESTS}

We declare that we have no conflict of interests.

\section{FUNDING SUPPORT}

There was no funding support in this research.

\section{REFERENCES}

1. Macleod J, Smith GD. Chlamydia screening can have high take-up rates if right methodology is used. BMJ. 1999;319:188-9.

2. Nelson HD, Helfand M. Screening for chlamydial infection. Am J Prev Med. 2001;20:95-107.

3. Fioravante FC, Alves MF, Guimarães EM, Turchi MD, Freitas HA, Domingos LT. Prevalence of Chlamydia trachomatis in asymptomatic Brazilian military conscripts. Sex Transm Dis. 2005;32:165-9. 
4. Gillespie CW, Manhart LE, Lowens MS, Golden MR. Asymptomatic urethritis is common and is associated with characteristics that suggest sexually transmitted etiology. Sex Transm Dis. 2013;40:271-4.

5. Miller WC, Ford CA, Morris M, Handcock MS, Schmitz JL, Hobbs MM, et al. Prevalence of chlamydial and gonococcal infections among young adults in the United States. JAMA. 2004;291:2229-36.

6. Cohen DA, Nsuami M, Etame RB, Tropez-Sims S, Abdalian $\mathrm{S}$, Farley TA, et al. A school-based Chlamydia control program using DNA amplification technology. Pediatrics.1998;101:E1.

7. Cecil JA, Howell MR, Tawes JJ, Gaydos JC, McKee KT Jr, Quinn TC, et al. Features of Chlamydia trachomatis and Neisseria gonorrhoeae infection in male Army recruits. J Infect Dis. 2001;184:1216-9.

8. LaMontagne DS, Fine DN, Marrazo JM. Chlamydia trachomatis infection in asymptomatic men. Am J Prev Med. 2003;24:3642 .

9. Hiltunen-Back E, Haikala O, Kautiainen H, Paavonen J, Reunala T. A nationwide sentinel clinic survey of Chlamydia trachomatis infection in Finland. Sex Transm Dis. 2001;28:252-8.

10. Laga M, Manoka A, Kivuvu M, Malele B, Tuliza M, Nzila N, Goeman J, et al. Non-ulcerative sexually transmitted diseases as risk factors for HIV-1 transmission in women: results from a cohort study. AIDS. 1993;7:95-102.
11. Fleming DT, Wasserheit JN. From epidemiological synergy to public health policy and practice: the contribution of other sexually transmitted diseases to sexual transmission of HIV infection. Sex Transm Infect. 1999;75:3-17.

12. Cohen MS, Hoffman IF, Royce RA, Kazembe P, Dyer JR, Daly $\mathrm{CC}$, et al. Reduction of concentration of HIV-1 in semen after treatment of urethritis: implications for prevention of sexual transmission of HIV-1. Lancet. 1997;349:1868-73.

13. Winter AJ, Taylor S, Workman J, White D, Ross JD, Swan AV, et al. Asymptomatic urethritis and detection of HIV-1 RNA in seminal plasma. Sex Transm Infect. 1999;75:261-3.

14. Lewis DA, Chirwa TF, Msimang VM, Radebe FM, Kamb ML, Firnhaber CS. Urethritis/cervicitis pathogen prevalenceand associated risk factors among asymptomatic HIV-infected patients in South Africa. Sex Transm Dis. 2012;39:531-6.

15. Farley TA, Cohen DA, Wu SY, Besch CL. The value of screening for sexually transmitted diseases in an HIV clinic. J Acquir Immun Defic Syndr. 2003;33:642-8.

16. White RG, Orroth KK, Glynn JR, Freeman EE, Bakker R, Habbema JD, et al. Treating curable sexually transmitted infections to prevent HIV in Africa: still an effective control strategy? J Acquir Immun Defic Syndr. 2008;47:346-53. 